\title{
In vivo and In vitro Management of Purple Blotch of Onion by Using Fungicides and Plant Extracts
}

\author{
Md. Mozidul Islam ${ }^{1}$, Fatema Begum ${ }^{2}$, Nazmoon Nahar ${ }^{3}$, U. A. Habiba ${ }^{4}$, K. M. Fakruzzaman ${ }^{5}$ \\ ${ }^{1}$ Assisstant Horticulture Development Officer, DAE, Burirhat, Rangpur, Bangladesh \\ ddhcrangpur5400[at]gmail.com \\ ${ }^{2 *}$ Corresponding author, Professor, Department of Plant Pathology, Sher-e-Bangla Agriculture University, Dhaka-1207, Bangladesh \\ fatema22_sau[at]yahoo.com \\ ${ }^{3}$ Lecturer, Agriculture, Taragonj O/A Government College, Taragonj, Rangpur, Bangladesh \\ nahernaz97[at]gmail.com \\ ${ }^{4}$ Undergraduate Student, Hajee Mohammad Danesh Science and Technology University, Dinajpur, Bangladesh
}

${ }^{5}$ Former Superintendent Engineer, Power Plant Commission, Operation \& Maintenance, Welfare (bd) Ltd, 33, SMC Tower Dhaka-1213, Bangladesh

\begin{abstract}
An investigation was carried on the management of purple blotch disease of onion (Alternaria porri) during 2015-2016 at BARI, Joydebpur, Gazipur, Bangladesh to see the effectiveness of fungicides in controlling the disease and evaluate the performance of some plant extracts in controlling purple blotch disease of onion seed crop. In in vivo, the effectiveness of 10 fungicides (Antracol, Folicur, Iindofil M-45, Metaril, Rovral, Score, Sulcox, Sun copperoxy, Unilax and Vonot 306) were screen against the disease. The fungicides were applied at $0.2 \%$, three times at 10 days interval. Of them Rovral appeared the best followed by Score. Folicur, Antracol, Metaril, Sulcox and Indofil M-45. More or less similar trend of the fungicides became evident when they were tested against Alerternaria porri in in vitro. While fungitoxicity of seven plants extracts (Dhatura, Dholkolmi, Garlic, Ginger, Marigold, Neem and Nymbicidine) was tested in field condition. Nymbicidine showed significantly the best performance in reducing the disease incidence and giving higher yield.
\end{abstract}

Keywords: Alternaria porri, Fungicides, Plant extract, Nimbicidine

\section{Introduction}

Onion (Allium cepa L.) is the most important one and familiar throughout the world and also used as popular vegetable among the spices crops. The major onion growing districts of Bangladesh are: Faridpur, Cumilla, Dhaka, Dinajpur, Jessore, Pabna and Rajshahi. It is an important vegetable in Australia, Belgium, India, Japan, United Kingdom, USA and some other countries. However, bulb onion is still the most popular here. The present production of onion is around 18, 67,000 MT from 4, 59, 000 acres of land [1],which is low compared to other onion growing countries of the world.

A number of diseases are associated with onion crops [2] [5].Among them the well documented disease is onion purple blotch incited by Alternaria porri (Ellis) which is noted as a major disease throughout the world including Bangladesh [4]- [7].In India, purple blotch of onion is a major devastating and widespread disease and causes serious yield reduction [8].The disease is also a threat for seed production of onion [9]-[11].

Damage of foliage and breaking of floral stalks due to purple blotch resulting failure of seed production of onion are common [2].[12]reported that the disease causes $41-44 \%$ yield loss in Bangladesh. [13]reported that under favorable environmental conditions complete failure of the crop takes place and there will be no seed setting. In India, the disease causes 20 to 25 per cent loss in seed yield [14].
Literatures from home and abroad indicate that many explored to find out suitable control methods of the disease, viz. resistant variety, date of planting, use of fertilizers, bulb size and chemical control with fungicides [16][23].Available literatures indicating quite a largenumber of plant species have been reported to have the antipathogenic activity [24]-[27].

In Bangladesh, no resistant source is available. The varieties grown in the country are highly susceptible to the disease. Role of environmental factors on disease development has not yet been studied systematically. Therefore, quite a little information is available on fungicidal control; and mostly those are on bulb production only [2], [10] but not on seed production. So, the present study was undertaken with the following objectives:

1) To screen the effectiveness of fungicides in controlling the disease and

2) To evaluate the performance of some plant extracts in controlling purple blotch disease of onion seed crop.

\section{Materials and Methods}

Experimental site: The experiment was conducted at the Plant Pathology Division, Bangladesh Agricultural Research Institute, Joydebpur, Gazipur, Bangladesh during 2015-2016 crop season. Three experiments were conducted for fulfilling the objectives. They were 1) Efficacy of some fungicides in controlling purple blotch disease of onion.2)

Volume 9 Issue 10, October 2020 www.ijsr.net 


\section{International Journal of Science and Research (IJSR)}

ISSN: 2319-7064

ResearchGate Impact Factor (2018): 0.28 | SJIF (2019): 7.583

Bioassay of fungicides and their concentrations in controlling growth of Alternaria porriin vitro and 3) Effect of plant extracts in controlling purple blotch disease of onion seed crop.

Preparation of soil: The field soil was sandy loam,was prepared for well tilth using a tractor driven disc plough rotavator and harrow. Then the soil clods were broken by hammer. After ploughing the field was left for 7 days for sun and air drying. Later, fertilizers were mixed with soil. TSP, MP, Urea and decomposed cowdung were applied.

Fertilizer application: Soil was fertilized with Nitrogen (in the form of urea), Phosphorus (in the form of Triple super phosphate-TSP), Potassium (in form of muriate of potashMP), Calcium (in the form of gypsum), Zinc (in the form of zinc oxide) and Boron (in the form of boric acid) [12]. Cowdung was applied during land preparation. Whole quantity of TSP, Gypsum, Zinc oxide, boric acid one third of Urea, were applied during final land preparation; the rest two third of urea was applied later in two installments (40 and 60 days after planting). Half of muriate of potash was applied at final land preparation and rest half was applied 40 days after planting. Cowdung was incorporated into soil at the rate of 10 tons per hectare during land opening.

Intercultural operation: A total of three times irrigation was done at 30, 60 and 90 days after transplanting by flood method.The dead or sick seedlings were replaced by healthy seedlings within a week after plantation. The damaged plants were also replaced by border plants through gap filling.Weeding and mulching were done as and when required to keep the crop free from weeds, for better soil aeration and conserve soil moisture. Mechanical support was provided in each plot using bamboo stick to keep the plant erect and to protect them from the damage caused by storm and high winds.

Collection of data: Data were recorded on lesion area, disease severity, PDI (Percent disease index), stem height, number of stem per hill, umbel diameter, weight of seeds/umbel, weight of seeds per plot, yield per plot was converted into yield per hectare. Lesion area was expressed in millimeter by measuring length and breadth of the leaves. Disease severity of purple blotch was assessed using 0-5 scale [13], as follows, by selecting 10 plants randomly from each plot and used for PDI (percent disease index) estimation.

$0=$ no disease symptoms

$1=\mathrm{a}$ few spots towards the tip, covering less than $10 \%$ leaf area

$2=$ several dark purplish brown patches covering less than $20 \%$ leaf area

$3=$ several patches with paler outer zone, covering up to $40 \%$ leaf area

$4=$ long streaks covering up to $75 \%$ leaf area or breaking of leaves/stems from the centre

$5=$ complete drying of the leaves/stems or breaking of the leaves/stems from the base.

The per cent disease index (PDI) was calculated by using formula given by [28], [29] as follows:

\author{
Total sum of numerical ratings \\ PDI $=\longrightarrow \times 100$ \\ Number of observation $x$ Maximum grading
}

Umbel diameter was taken by randomly selecting 10 umbels from each replication. Weight of seeds/umbel was assessed by recording seed weight of 10 umbels per replication.The crop was harvested within 100 -125 days after transplanting.

\section{Efficacy of some Fungicides in Controlling Purple Blotchof Onion}

Seedlings of local cultivars were included under the study. The unit plot size was $2.0 \times 2.0 \mathrm{~m}$, keeping $20 \mathrm{~cm}$ and $10 \mathrm{~cm}$ spacing respectively for row to row and plant to plant.Apparently healthy seedlings were transplanted on 20.12.15.

Treatments (Fungicides): The experiment consisted of 11 treatments including control. The treatments were as follows:

$\begin{array}{llll}\mathrm{T}_{1}= & \text { Antracol } & \mathrm{T}_{7}= & \text { Sulcox } \\ \mathrm{T}_{2}= & \text { Folicur } & \mathrm{T}_{8}= & \text { Sun copperoxy } \\ \mathrm{T}_{3}= & \text { Indofil M-45 } & \mathrm{T}_{9}= & \text { Unilax } \\ \mathrm{T}_{4}= & \text { Metaril } & \mathrm{T}_{10}= & \text { Vondozeb } \\ \mathrm{T}_{5}= & \text { Rovral } & \mathrm{T}_{11}= & \text { Control } \\ \mathrm{T}_{6}= & \text { Score } & & \end{array}$

Application of fungicides: Spray of fungicides was initiated after the disease symptoms detected in the experimental plot. A total of three sprays were performed at an interval of 10 days. The experimentwas scheduled following RCBDhaving three replications.

\section{Bioassay of Fungicides and their Concentrations in ControllingGrowth of Alternaria porri inin vitro Collection and Isolation of the fungus}

Ideal purple blotch diseased samples of onion was collected from experimental field of BARI, Gazipur and brought in the Plant Pathology Central Laboratory. Diseased samples were processed into small pieces, sterilized with $10 \%$ chlorox solution for three minutes, rinsed with sterile water and finally placed on Petri plates $(9 \mathrm{~cm}$ dia.) containing host extract media. The composition of the host extract Media were onion leaf $(200 \mathrm{~g})$, dextrose $(15 \mathrm{~g})$, agar $(20 \mathrm{~g})$ and water $(1000 \mathrm{ml})$. Onion leaf was cut into small pieces, put in $500 \mathrm{ml}$ water andboiled for 30 minutes. Then supernatant extract was decanted. Within the supernatant other ingredients were added with rest quantity of water to make one litre. The medium was then autoclaved at $121^{\circ} \mathrm{C}$ at 15 PSI for 20 minutes. Aftersterilization the medium (at $40-45^{\circ} \mathrm{C}$ ) was poured at the rate of $20 \mathrm{ml}$ per Petri plates. After solidifying of the media inoculated Petri plates were incubated at $25 \pm 1^{\circ} \mathrm{C}$ for five days. The isolated fungus was identified by using the keys outlined by [30].

Multiplication of $A$. porri: Pure culture of $A$. porri was multiplied on PDA (Potato $200 \mathrm{~g}$, Dextrose $15 \mathrm{~g}$, Agar $20 \mathrm{~g}$, water $1000 \mathrm{ml}$ ) Petri plates by hyphal tip method.

Fungicides used: Ten fungicides namely, Antracol, Folicur, Indofil M-45, Metaril, Rovral, Score, Sulcox, Sun Copperoxy, Unilax and Vondozeb were included in the study.

Concentration of Fungicides and its preparation: Fungicides were used in four concentrations. Those were

Volume 9 Issue 10, October 2020 


\section{International Journal of Science and Research (IJSR) \\ ISSN: 2319-7064}

ResearchGate Impact Factor (2018): 0.28 | SJIF (2019): 7.583

2000, 1000, 500 and $250 \mathrm{ppm}$. Requisite quantities of fungicides were mixed in fixed quantity of distilled water to achieve desired concentrations. In case of control, only sterile water was used. Each concentration was replicated thrice.

Bioassay of Fungicides: Poisoned food technique was followed [31]. Potato dextrose agar medium was used and poured at the rate of $15 \mathrm{ml}$ per Petri plate $(9 \mathrm{~cm})$. Before pouring of medium one $\mathrm{ml}$ of fungicidal solution (for each concentration of fungicides) was added in each Petri plate. After adding medium the plates were shaken in swirling motion for uniform mixing.

After solidifying of the media, the centre of each Petri plate was inoculated with a $3 \mathrm{~mm}$ mycelial disc, cut from the edge of 10 days old fresh culture of A. porri. The inoculated Petri plates were then incubated at $25 \pm 1^{\circ} \mathrm{C}$ for 10 days.

Collection of data: After incubation the mycelia growth of the fungus from each concentration of the fungicide was recorded.

Design: The experiment was arranged following Completely Randomised Design.

\section{Effect of Plant Extracts in Controlling Purple Blotch} Disease ofOnion Seed Crop

Treatments (Plant extracts): There were eight treatment including control. The treatments were as follows:

\begin{tabular}{|c|c|c|}
\hline Treatment & Common Name & Scientific Name \\
\hline $\mathrm{T}_{1}$ & Dhatura & Datura alba \\
\hline $\mathrm{T}_{2}$ & Dholkalmi & Ipomoea fistulosa \\
\hline $\mathrm{T}_{3}$ & Garlic & Allium sativum \\
\hline $\mathrm{T}_{4}$ & Ginger & Gingiberofficinale \\
\hline $\mathrm{T}_{5}$ & Marigold & Tagetespatula \\
\hline $\mathrm{T}_{6}$ & Neem & Azadirachta indica \\
\hline $\mathrm{T}_{7}$ & Nymbicidine & Azadirachta indica \\
\hline $\mathrm{T}_{8}$ & Control & - \\
\hline
\end{tabular}

From $\mathrm{T}_{1}$ to $\mathrm{T}_{6}$, the dose of each extract was used at the rate of $15 \mathrm{ml}$ per $1000 \mathrm{ml}$ water. Treatment $\mathrm{T}_{7}$, Nymbicidine was applied at the rate of $0.2 \%$ per $1000 \mathrm{ml}$ water.

Application of Plant Extracts: A total of five sprays were scheduled at 10 days interval, initiating just after the onset of disease symptom in experimental field.

Analysis of data: Data were analysed statistically using MSTAT-C computer Program. Data were transformed, whenever necessary, following Arcsine transformation. Means of treatments were separated using Duncan's Multiple Range Test (DMRT) [32].

\section{Results}

\subsection{Efficacy of Some Fungicides in Controlling Purple Blotch Disease of Onion}

There was significant variations among the fungicides in relation to disease parameters of purple blotch disease of onion and the corresponding effects on yield (Table 1 and 2).
The effect of fungicides on plant height ranged from 27.8 $37.9 \mathrm{~cm}$. The highest plant height was recorded in plants where Rovral was applied and it appeared statistically similar to those of Antracol, Folicur, Indofil M-45, Metaril, Score, Sulcox and Sun Copperoxy. Significantly the lowest plant height was recorded under the control treatment, where only plain water was sprayed; but it showed statistically insignificant compared with the fungicides like Sun Copperoxy, Unilax and Vondozeb.

In case of leaf number per seedling existence of difference among the treatments became evident. It ranged from $3.9-$ 6.4. The effect of fungicides like Antracol, Folicur, Rovral and score on producing leaf number per seedling were insignificant. The minimum of 3.9 leaves per seedling was recorded under control and it gave statistically similar response after treatments with lndofil M-45, Sun Copperoxy, Unilax and Vondozeb. The maximum $\left(31.9 \mathrm{~mm}^{2}\right)$ and the minimum $\left(14.33 \mathrm{~mm}^{2}\right)$ lesion area were assessed respectively under control and Rovral. Among the tested fungicides, Rovralappeared the best in minimizing lesion area of purple blotch; followed by Score $\left(15.93 \mathrm{~mm}^{2}\right)$, Folicur $\left(17.13 \mathrm{~mm}^{2}\right)$,Antracol $\left(19.20 \mathrm{~mm}^{2}\right)$, Metaril $(19.20$ $\left.\mathrm{mm}^{2}\right)$, Sulcox $\left(20.4 \mathrm{~mm}^{2}\right)$, Indofil M-45 $\left(21.56 \mathrm{~mm}^{2}\right)$, Sun Copperoxy $\left(22.1 \mathrm{~mm}^{2}\right)$, Unilax $\left(23.06 \mathrm{~mm}^{2}\right)$ and Vondozeb $\left(29.63 \mathrm{~mm}^{2}\right)$. The fungitoxicities of Antracol, Folicur, Indofil M-45, Metaril, Rovral, Score, Sulcox and Sun Copperoxy in reducing lesion area of A. porri, were statistically similar. These fungicides, however, varied significantly withUnilax, Vondozeb and control. The effect of Unilax was statistically similar to that of Vondozeb but it (Unilax) differed significantly with the control.

The effectiveness of the fungicides in reducing PDI of purple blotch can be arranged in ascending order as: Rovral(32.0\%), Score (36.0\%), Folicur (40.66\%), Antracol (42.0\%), Metaril (45.33\%), Sulcox (50.66\%), Indofil M-45 $(52.00 \%)$, Sun Copperoxy $(56.0 \%)$, Unilax (57.33\%), Vondozeb (58.66\%) and Control $(72.00 \%)$. When statistical analysis was performed it was found that Rovral proved to be the best one in minimizing PDI significantly and it appeared statistically similar to that of Score (Fig. 1), Folicur and Antracol but differed significantly with the rest of the treatments. Among the fungicides Vondozeb appeared as least effective and gave the maximum PDI value of the disease numerically but the values was statistically identical with Unilax, Sun copperoxy, Sulcox and Indofil M-45. Through Indofil M-45 appeared statistically insignificant to Antracol and Folicur but it gave significantly higher PDI compared to Score and Rovral (Fig. 2). Based on the parameter of reduction of PDI over control, it was found that the maximum PDI of purple blotch was reduced by the application of Rovral (55.55\%), followed by score (50.0\%), Folicur (43.52\%), Antracol (41.66\%), Metaril (37.04\%), Sulcox (29.63\%), Indofil M-45 (27.77\%), Sun Copperoxy (22.22\%), Unilax (20.37\%) and Vondozeb (18.52\%).

Results obtained from yield contributing parameters indicated the presence of significant differences among the used fungicides. Bulb diameter among the treatments, ranged from 24.17-30.64 $\mathrm{mm}$; where the minimum and the maximum was recorded from control and Rovral, respectively. There was no other significant difference

Volume 9 Issue 10, October 2020 


\section{International Journal of Science and Research (IJSR) \\ ISSN: 2319-7064}

ResearchGate Impact Factor (2018): 0.28 | SJIF (2019): 7.583

among the fungicides on this parameter. Significantly lower bulb diameter was measuredfrom control and it was statistically alike with Indofil M-45, Sulcox, Sun Copperoxy, Unilax and Vondozeb.

In respect of bulb weight per plant, the highest bulb weight was assessed from Rovral treated plants $(26.63 \mathrm{~g})$ which was followed by Score (25.9g), Folicur (24.85g), Antracol (23.65g), Metaril (20.94g), Sulcox (18.86g), Indofil (18.22g), Sun Copperoxy (18.06g), Unilax (18.05g), Vondozeb (15.86g) and control (15.03g). Statistical analysis revealed that significantly higher per plant bulb weight was incurred by Rovral; its differences were insignificant with Score, Folicur, Antracol and Metaril. Metaril again showed statistical similar it's in terms of effect on bulb weight per plant, with Indofil, Sulcox, Sun Copperoxy, Unilax, Vondozeb and the Control. Regarding, bulb weight, the performance of fungicides in order of descending, can be arranged as : Rovral (2.79kg), Score (2.72 kg), Folicur (2.64 $\mathrm{kg})$, Antracol (2.54 kg), Metaril (2.47 kg), Sulcox (2.35 kg), Indofil $(2.22 \mathrm{~kg})$, Sun Copperoxy $(2.08 \mathrm{~kg})$, Unilax $(2.07$ $\mathrm{kg}$ ), Vondozeb (2.04 kg) and Control $(1.98 \mathrm{~kg})$. However, significantly lower bulb yield was harvested from control which was statistically at par with Vondozeb, Unilax, Sun Copperoxy, Sulcox and Indofil. When bulb yield was converted to determine the percent yield increased over control, due to application of fungicides it appeared that $28.28,33.33,12.12,24.72,40.90,37.37,18.68,5.05,4.54$ and $3.03 \%$ more yields were obtained respectively (Fig. 2), by using Antracol, Folicur, Indofil, Metaril, Rovral, Score, Sulcox, Sun Copperoxy, Unilax and Vondozeb.

Table 1:Effect of different fungicides in controlling purple blotch disease of onion

\begin{tabular}{|c|c|c|c|c|}
\hline Treatment & $\begin{array}{c}\text { No. of } \\
\text { leaff } \\
\text { seedling }\end{array}$ & $\begin{array}{c}\text { Plant } \\
\text { height } \\
(\text { cm })\end{array}$ & $\begin{array}{c}\text { Lesion } \\
\text { area } \\
(\text { sq.mm })\end{array}$ & \%PDI \\
\hline $\mathrm{T}_{1}=$ Antracol & $5.5 \mathrm{abc}$ & $35.9 \mathrm{a}$ & $19.20 \mathrm{~cd}$ & $42.00 \mathrm{def}(6.47)$ \\
\hline $\mathrm{T}_{2}=$ Folicur & $5.8 \mathrm{ab}$ & $36.7 \mathrm{a}$ & $17.13 \mathrm{~cd}$ & $40.66 \mathrm{def}(6.67)$ \\
\hline $\mathrm{T}_{3}=$ Indofil M-45 & $4.5 \mathrm{~cd}$ & $33.5 \mathrm{abc}$ & $21.56 \mathrm{~cd}$ & $52.00 \mathrm{bcd}(7.20)$ \\
\hline $\mathrm{T}_{4}=$ Metaril & $5.3 \mathrm{bc}$ & $35.1 \mathrm{a}$ & $19.40 \mathrm{~cd}$ & $45.33 \mathrm{cde}(6.72)$ \\
\hline $\mathrm{T}_{5}=$ Rovral & $6.4 \mathrm{a}$ & $37.9 \mathrm{a}$ & $14.33 \mathrm{~d}$ & $32.00 \mathrm{f}(5.65)$ \\
\hline $\mathrm{T}_{6}=$ Score & $6.1 \mathrm{ab}$ & $36.8 \mathrm{a}$ & $15.93 \mathrm{~cd}$ & $36.00 \mathrm{ef}(5.99)$ \\
\hline $\mathrm{T}_{7}=$ Sulcox & $5.2 \mathrm{bc}$ & $34.5 \mathrm{ab}$ & $20.40 \mathrm{~cd}$ & $50.66 \mathrm{bcd}(7.09)$ \\
\hline $\begin{array}{c}\mathrm{T}_{8}=\text { Sun } \\
\text { Copperoxy }\end{array}$ & $4.5 \mathrm{~cd}$ & $33.2 \mathrm{abc}$ & $22.10 \mathrm{~cd}$ & $56.00 \mathrm{bc}(7.46)$ \\
\hline $\mathrm{T}_{9}=$ Unilax & $4.1 \mathrm{~d}$ & $29.3 \mathrm{bc}$ & $23.06 \mathrm{bc}$ & $57.33 \mathrm{~b}(7.56)$ \\
\hline $\mathrm{T}_{10}=$ Vondozeb & $4.1 \mathrm{~d}$ & $28.0 \mathrm{c}$ & $29.63 \mathrm{ab}$ & $58.66 \mathrm{~b}(7.62)$ \\
\hline $\mathrm{T}_{11}=$ Control & $3.9 \mathrm{~d}$ & $27.8 \mathrm{c}$ & $31.90 \mathrm{a}$ & $72.00 \mathrm{a}(8.47)$ \\
\hline
\end{tabular}

- Means bearing same letter within the same column do not differ significantly at 5\% level following DMRT.

— Figures in parenthesis indicate transformed value.

Table 2:Effect of different fungicides on yield contributing characters of purple blotch of onion

\begin{tabular}{|c|c|c|c|}
\hline Treatment & $\begin{array}{c}\text { Diameter } \\
(\text { mm }) / \text { bulb }\end{array}$ & $\begin{array}{c}\text { Weight } \\
(\mathrm{gm}) / \mathrm{bulb}\end{array}$ & $\begin{array}{c}\text { Bulb weight } \\
(\mathrm{kg}) / \text { plot }\end{array}$ \\
\hline $\mathrm{T}_{1}=$ Antracol & $29.84 \mathrm{a}$ & $23.65 \mathrm{a}$ & $2.54 \mathrm{ab}$ \\
\hline $\mathrm{T}_{2}=$ Folicur & $30.40 \mathrm{a}$ & $24.85 \mathrm{a}$ & $2.64 \mathrm{ab}$ \\
\hline $\mathrm{T}_{3}=$ Indofil M-45 & $28.50 \mathrm{ab}$ & $18.22 \mathrm{~b}$ & $2.22 \mathrm{bcd}$ \\
\hline $\mathrm{T}_{4}=$ Metaril & $29.5 \mathrm{a}$ & $20.94 \mathrm{ab}$ & $2.47 \mathrm{abc}$ \\
\hline $\mathrm{T}_{5}=$ Rovral & $30.64 \mathrm{a}$ & $26.63 \mathrm{a}$ & $2.79 \mathrm{a}$ \\
\hline $\mathrm{T}_{6}=$ Score & $30.45 \mathrm{a}$ & $25.90 \mathrm{a}$ & $2.72 \mathrm{a}$ \\
\hline $\mathrm{T}_{7}=$ Sulcox & $28.73 \mathrm{ab}$ & $18.86 \mathrm{~b}$ & $2.35 \mathrm{a} \mathrm{bcd}$ \\
\hline
\end{tabular}

\begin{tabular}{|c|c|c|c|}
\hline $\mathrm{T}_{8}=$ Sun Copperoxy & $28.05 \mathrm{ab}$ & $18.06 \mathrm{~b}$ & $2.08 \mathrm{~cd}$ \\
\hline $\mathrm{T}_{9}=$ Unilax & $26.89 \mathrm{ab}$ & $18.05 \mathrm{~b}$ & $2.07 \mathrm{~cd}$ \\
\hline $\mathrm{T}_{10}=$ Vondozeb & $25.70 \mathrm{ab}$ & $15.86 \mathrm{~b}$ & $2.04 \mathrm{~cd}$ \\
\hline $\mathrm{T}_{11}=$ Control & $24.17 \mathrm{~b}$ & $15.03 \mathrm{~b}$ & $1.98 \mathrm{~d}$ \\
\hline
\end{tabular}

-Means bearing same letter within the same column do not differ significantly at 5\% level following DMRT
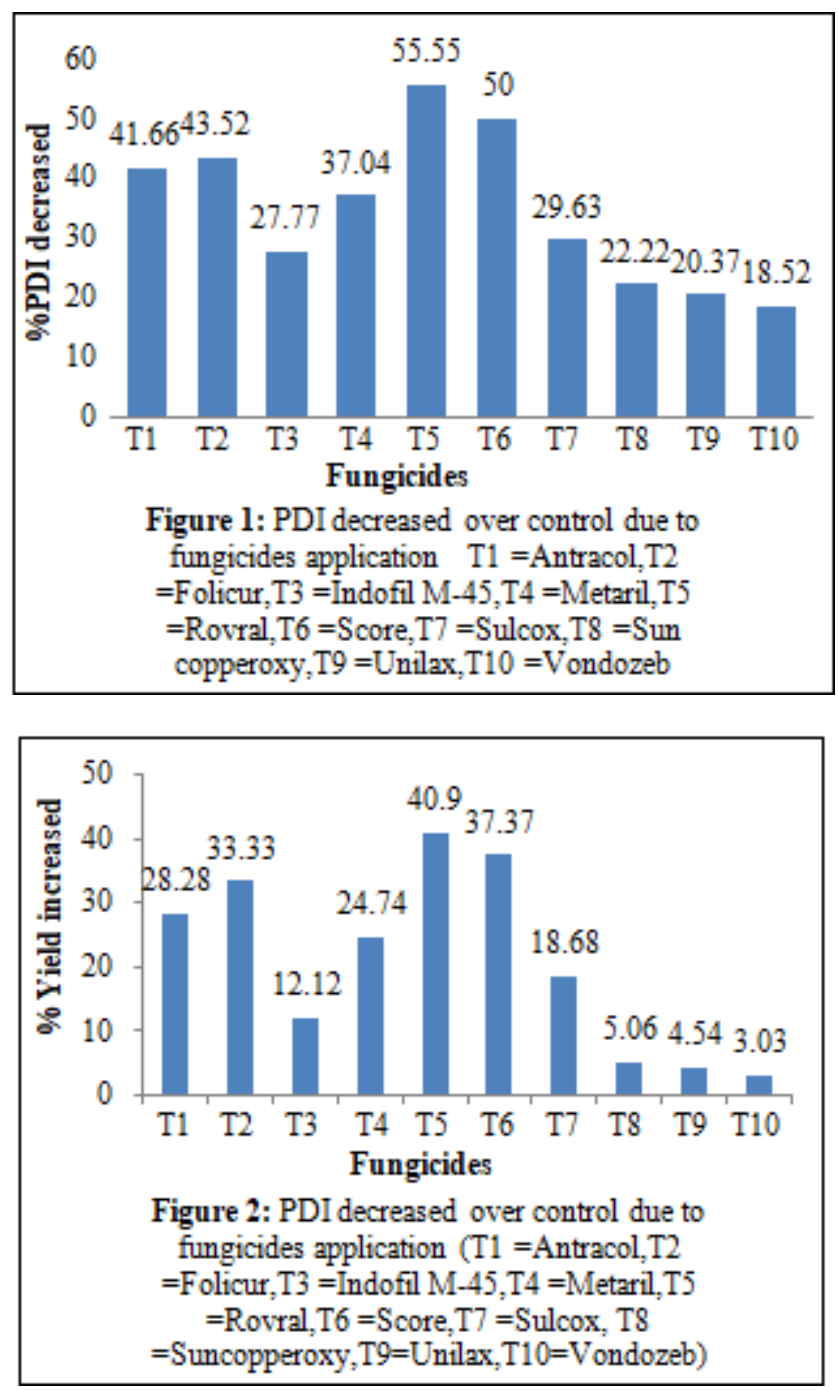

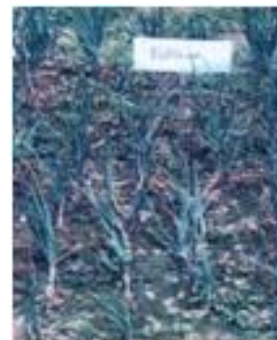

Folicure

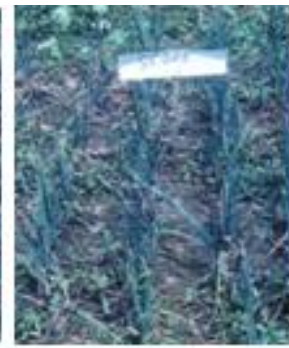

Score

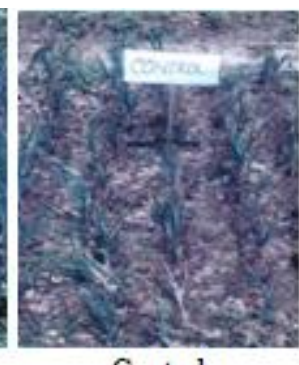

Control
Plate 1: Effectiveness of fungicides in controlling purple blotch of onion

\subsection{Bioassay of fungicides and their concentrations in controllinggrowth of Alternaria porri in vitro}

Results on the effectiveness of fungicides and their concentrations on mycelial growth of A. porri are presented in Table 3. Irrespective of concentrations, Rovral and Score appeared the best in controlling growth of $A$. porri and they showed statistically similar effect. The fungicide Folicur 


\section{International Journal of Science and Research (IJSR) \\ ISSN: 2319-7064}

ResearchGate Impact Factor (2018): 0.28 | SJIF (2019): 7.583

was highly effective at higher concentrations (2000 and $1000 \mathrm{ppm}$ ) and showed statistically similar with Rovral and Score even at their lowest concentration (250 ppm). Folicur at 500 and $250 \mathrm{ppm}$ has shown statistically insignificant effect on mycelial growth of the fungus. The fungicides; Antracol, Sulcox and Metaril exhibited statistically similar effect with their highest concentration (2000 ppm) against $A$. porri and they showed statistically insignificant with Folicur at $500 \mathrm{ppm}$. Vondozeb failed to prove its effectiveness in restricting the growth of the fungus even at its highest concentration. More or less similar trend of in effectivness of Unilax became evident during performing of the study. Sun Copperoxy and Indofil M-45 was less effective against A. porri to check the growth even at the highest concentration. The maximum mycelia growth of the fungus was recorded in control $(9.0 \mathrm{~cm})$ where plain sterile water was added and the growth was statistically similar to those of Sulcox (500 and $250 \mathrm{ppm}$ ), Sun Copperoxy (500 and 250 ppm), Metaril (250 ppm),Vondozeb (2000, 1000, 500 and $250 \mathrm{ppm}$ ) and Unilax (500 and $250 \mathrm{ppm})$.

Table 3: Efficacy of some fungicides and their concentrations on mycelial growth of Alternaria porri in In vitro

\begin{tabular}{|c|c|c|c|c|}
\hline \multirow{2}{*}{ Fungicide } & \multicolumn{4}{|c|}{ Mycelial growth $(\mathrm{cm})$} \\
\cline { 2 - 5 } & $2000 \mathrm{ppm}$ & $1000 \mathrm{ppm}$ & $500 \mathrm{ppm}$ & $250 \mathrm{ppm}$ \\
\hline $\mathrm{T}_{1}=$ Antracol & $2.967 \mathrm{j}$ & $3.233 \mathrm{ij}$ & $5.883 \mathrm{fgh}$ & $6.987 \mathrm{~b}-\mathrm{f}$ \\
\hline $\mathrm{T}_{2}=$ Folicur & $1.167 \mathrm{k}$ & $1.617 \mathrm{k}$ & $3.083 \mathrm{ij}$ & $4.517 \mathrm{hi}$ \\
\hline $\mathrm{T}_{3}=$ Indofil M-45 & $5.317 \mathrm{gh}$ & $6.283 \mathrm{~d}-\mathrm{g}$ & $6.283 \mathrm{~d}-\mathrm{g}$ & $7.133 \mathrm{~b}-\mathrm{f}$ \\
\hline $\mathrm{T}_{4}=$ Metaril & $3.450 \mathrm{ij}$ & $5.350 \mathrm{gh}$ & $7.100 \mathrm{~b}-\mathrm{f}$ & $7.750 \mathrm{a}-\mathrm{d}$ \\
\hline $\mathrm{T}_{5}=$ Rovral & $0.650 \mathrm{k}$ & $1.000 \mathrm{k}$ & $1.283 \mathrm{k}$ & $1.333 \mathrm{k}$ \\
\hline $\mathrm{T}_{6}=$ Score & $0.766 \mathrm{k}$ & $1.050 \mathrm{k}$ & $1.277 \mathrm{k}$ & $1.503 \mathrm{k}$ \\
\hline $\mathrm{T}_{7}=$ Sulcox & $3.483 \mathrm{ij}$ & $7.050 \mathrm{~b}-\mathrm{f}$ & $8.000 \mathrm{abc}$ & $8.367 \mathrm{ab}$ \\
\hline $\mathrm{T}_{8}=$ Sun Copperoxy & $6.017 \mathrm{efg}$ & $6.550 \mathrm{c}-\mathrm{g}$ & $7.717 \mathrm{a}-\mathrm{d}$ & $8.067 \mathrm{abc}$ \\
\hline $\mathrm{T}_{9}=$ Unilax & $6.850 \mathrm{~b}-\mathrm{f}$ & $6.400 \mathrm{~d}-\mathrm{g}$ & $7.467 \mathrm{a}-\mathrm{e}$ & $8.750 \mathrm{a}$ \\
\hline $\mathrm{T}_{10}=$ Vondozeb & $7.817 \mathrm{a}-\mathrm{d}$ & $8.067 \mathrm{abc}$ & $8.210 \mathrm{a}-\mathrm{b}$ & $8.967 \mathrm{a}$ \\
\hline $\mathrm{T}_{11}=$ Control & $9.000 \mathrm{a}$ & $9.000 \mathrm{a}$ & $9.000 \mathrm{a}$ & $9.000 \mathrm{a}$ \\
\hline
\end{tabular}

-Means bearing same letter within the same column do not differ significantly at 5\% level following DMRT.

\subsection{Effect of Plant Extracts in Controlling Purple Blotch Disease of Onion Seed Crop}

Significant differences among the effects of plant extracts became evident in controlling purple blotch of onion as well as in the seed contributing characters (Tables 4 and 5). The maximum stem height was recorded in the crops where Dhatura $\left(\mathrm{T}_{1}\right)$ extract $(62.09 \mathrm{~cm})$ was applied followed by $\mathrm{T}_{6}$ (Neem), $\mathrm{T}_{7}$ (Nymbicidine), $\mathrm{T}_{4}$ (Ginger), $\mathrm{T}_{3}$ (Garlic), $\mathrm{T}_{8}$ (Control), $\mathrm{T}_{5}$ (Marigold) and $\mathrm{T}_{2}$ (Dholkalmi). Statistical analysis revealed that significantly higher stem height was measured under the treatment $\mathrm{T}_{1}$ and this was statistically similar to $\mathrm{T}_{6}$ and Nymbicidine $\left(\mathrm{T}_{7}\right)$ but differed significantly with the rest of the treatments (Table 4 ). The treatment $T_{2}$ gave the lowest stem height and the differences were statistically insignificant with $\mathrm{T}_{3}, \mathrm{~T}_{5}$ and $\mathrm{T}_{8}$. In case of stem number per hill, it ranged from 1.86-2.47, where the minimum and the maximum number of stem per hill were recorded in $\mathrm{T}_{8}$ and $\mathrm{T}_{1}$, respectively. The effect of treatments on producing number of stem per hill under the treatments $\mathrm{T}_{1}, \mathrm{~T}_{2}, \mathrm{~T}_{4}, \mathrm{~T}_{5}, \mathrm{~T}_{6}$ and $\mathrm{T}_{7}$ were insignificant. Significantly fewer numberof stem per hill was recorded in $T_{8}$ which was statistically similar to those of $\mathrm{T}_{2}$ and $\mathrm{T}_{3}$.
The differences on the effects of plant extracts on the lesionarea were also pronounced under the study and it ranged from $18.40-25.90 \mathrm{~mm}^{2}$. In order of affectivity of plant extracts in reducing the lesion area of purple blotch, the treatments can be arranged as: $\mathrm{T}_{7}\left(18.40 \mathrm{~mm}^{2}\right), \mathrm{T}_{6}(19.13$ $\left.\mathrm{mm}^{2}\right), \mathrm{T}_{3}\left(19.20 \mathrm{~mm}^{2}\right), \mathrm{T}_{1}\left(20.40 \mathrm{~mm}^{2}\right), \mathrm{T}_{2}\left(20.60 \mathrm{~mm}^{2}\right), \mathrm{T}_{4}$ $\left(21.33 \mathrm{~mm}^{2}\right), \mathrm{T}_{8}\left(25.10 \mathrm{~mm}_{2}\right)$ and $\mathrm{T}_{5}\left(25.90 \mathrm{~mm}^{2}\right)$. Significantly better response in minimizing the purple blotch lesion area was measured under the treatment $T_{7}$ which differed significantly with all the rest of the treatments. The effect of treatments noted at $\mathrm{T}_{1}, \mathrm{~T}_{2}, \mathrm{~T}_{3}, \mathrm{~T}_{4}$ and $\mathrm{T}_{6}$ showed statistically similar in reducing lesion area and they showed significantly lower lesion area compared to those of $\mathrm{T}_{5}$ and $\mathrm{T}_{8}$. Regarding PDI value, the minimum PDI was computed at $\mathrm{T}_{7}(37.66 \%)$. The treatment, $\mathrm{T}_{1}$; ranked next to $\mathrm{T}_{7}$ followed by $\mathrm{T}_{6}(43.66 \%) ; \mathrm{T}_{2}(45.66 \%), \mathrm{T}_{4}(52.00 \%), \mathrm{T}_{3}$ (64.00); $\mathrm{T}_{5}(64.00 \%)$ and $\mathrm{T}_{8}(86.33 \%)$. Statistical analysis revealed that, among the plant extracts, Nymbicidine $\left(\mathrm{T}_{7}\right)$ was the best, which significantly reduced the PDI of purple blotch compared to the others ones except $T_{1}$. The differences between the reductions of PDI under the treatments $T_{1}$ and $T_{6}$ was insignificant and the treatments gave significantly lower PDI compared to $\mathrm{T}_{2}, \mathrm{~T}_{3}, \mathrm{~T}_{4}, \mathrm{~T}_{5}$ and $\mathrm{T}_{8}$ (Fig. 3). The treatments $\mathrm{T}_{2}, \mathrm{~T}_{4}$ and $\mathrm{T}_{6}$ showed statistically similar performance on reduction of PDI. Treatment $\mathrm{T}_{8}$ has shown significantly higher PDI and it differed significantly with the rest of the treatments. The maximum PDI reduced over control was shown by $\mathrm{T}_{7}(56.37 \%)$ followed by $\mathrm{T}_{6}$ (51.20\%), $\mathrm{T}_{1}(49.84 \%), \mathrm{T}_{2}(47.10 \%), \mathrm{T}_{4}(39.76 \%)$ and $\mathrm{T}_{3}$ and $\mathrm{T}_{5}(30.49 \%)$.

The treatments showed a wide variation on yield contributing parameters both numerically and statistically. The influence of treatments (Plant extracts) on umbel diameters ranged from 46.23- $53.83 \mathrm{~mm}$. The maximum umbel diameter was recorded in $\mathrm{T}_{7}$ followed by $\mathrm{T}_{6}(52.46$ $\mathrm{mm}), \mathrm{T}_{1}(51.69 \mathrm{~mm}), \mathrm{T}_{4}(50.55 \mathrm{~mm}), \mathrm{T}_{5}(49.67 \mathrm{~mm}), \mathrm{T}_{3}$ (48.67 mm), $\mathrm{T}_{2}(48.43 \mathrm{~mm})$ and $\mathrm{T}_{8}(46.23 \mathrm{~mm})$. The umbel diameter recorded by $\mathrm{T}_{7}$ differed significantly with those of other treatments (Table5). However, there was no significant variation between the treatments, $\mathrm{T}_{1}$ and $\mathrm{T}_{6}$ on umbel diameter; so were $\mathrm{T}_{4}$ and $\mathrm{T}_{5}$. Significantly lowerumbel diameter was recorded in $\mathrm{T}_{8}$ and it differed significantly with the rest of the treatments.

In case of weight of seed per umbel, significantly higher amount of seed was harvested from the umbels of $\mathrm{T}_{6}$ treated plots but statistically it showed similar effects with all the rest of the treatments except $T_{8}$, where no plant extract was sprayed. Though significantly lower seed weight per umbel was assessed in $\mathrm{T}_{8}$, it was statistically similar to those of $\mathrm{T}_{2}$, $\mathrm{T}_{3}, \mathrm{~T}_{4}, \mathrm{~T}_{5}$ and $\mathrm{T}_{7}$.

The yield per plot ranged from 55.00-135.00g with the minimum and the maximum given by $T_{8}$ and $T_{7}$, respectively. The treatment $T_{6}$ gave the second highest per plot seed yield $(109.30 \mathrm{~g})$ followed by $\mathrm{T}_{1}(92.67 \mathrm{~g}), \mathrm{T}_{5}$ (82.67g), $\mathrm{T}_{4}(72.00 \mathrm{~g}), \mathrm{T}_{3}(66.00 \mathrm{~g})$ and $\mathrm{T}_{2}(65.00 \mathrm{~g})$ (Table 5). Statistical analysis indicated that significantly higher seed yield was harvested under the treatment $T_{7}$ and it differed significantly with all other treatments. The treatment $\mathrm{T}_{6}$ gave significantly lower seed yield than $T_{7}$, but gave significantly higher per plot seed yield over $T_{1}, T_{2}, T_{3}, T_{4}, T_{5}$ and $T_{8}$. The effect of $\mathrm{T}_{1}$ and $\mathrm{T}_{5}$ on per plot seed yield was insignificant.

Volume 9 Issue 10, October 2020 www.ijsr.net 


\title{
International Journal of Science and Research (IJSR) \\ ISSN: 2319-7064
}

ResearchGate Impact Factor (2018): 0.28 | SJIF (2019): 7.583

Again, the effect of $\mathrm{T}_{2}, \mathrm{~T}_{3}$ and $\mathrm{T}_{4}$ on same parameters was insignificant among themselves. About 68.49, 18.18, 20.00, $30.90,50.30,98.72$ and $145.45 \%$ yield increased over control was estimated respectively, by those of $T_{1}, T_{2}, T_{3}$, $\mathrm{T}_{4}, \mathrm{~T}_{5}, \mathrm{~T}_{6}$ and $\mathrm{T}_{7}$ treatments (Fig.4).

Table 4: Fungi toxicity of some plant extracts in controlling purpleblotch of onion seed crop

\begin{tabular}{|c|c|c|c|c|}
\hline Treatment & $\begin{array}{c}\text { Stem } \mathrm{ht} . \\
(\mathrm{cm})\end{array}$ & Stem/hill & $\begin{array}{c}\text { Lesion area } \\
\left(\mathrm{mm}^{2}\right)\end{array}$ & $\% P D I$ \\
\hline $\mathrm{T}_{1}=$ Dhatura & $62.09 \mathrm{a}$ & $2.47 \mathrm{a}$ & $20.40 \mathrm{~b}$ & $43.30 \mathrm{de}(6.58)$ \\
\hline $\mathrm{T}_{2}=$ Dholkalmi & $57.74 \mathrm{~d}$ & $2.17 \mathrm{abc}$ & $20.60 \mathrm{~b}$ & $45.66 \mathrm{c}(6.75)$ \\
\hline $\mathrm{T}_{3}=$ Garlic & $59.42 \mathrm{bcd}$ & $1.93 \mathrm{bc}$ & $19.20 \mathrm{~b}$ & $64.00 \mathrm{~b}(8.00)$ \\
\hline $\mathrm{T}_{4}=$ Ginger & $59.87 \mathrm{bc}$ & $2.23 \mathrm{ab}$ & $21.33 \mathrm{~b}$ & $52.00 \mathrm{c}(7.21)$ \\
\hline $\mathrm{T}_{5}=$ Marigold & $58.13 \mathrm{~cd}$ & $2.20 \mathrm{ab}$ & $25.90 \mathrm{a}$ & $64.00 \mathrm{~b}(8.00)$ \\
\hline $\mathrm{T}_{6}=$ Neem & $61.22 \mathrm{ab}$ & $2.40 \mathrm{a}$ & $19.13 \mathrm{~b}$ & $43.66 \mathrm{~cd}(6.60)$ \\
\hline $\mathrm{T}_{7}=$ Nymbicidine & $61.19 \mathrm{ab}$ & $2.43 \mathrm{a}$ & $18.40 \mathrm{c}$ & $37.66 \mathrm{e}(6.13)$ \\
\hline $\mathrm{T}_{8}=$ Control & $58.48 \mathrm{~cd}$ & $1.86 \mathrm{c}$ & $25.10 \mathrm{a}$ & $86.33 \mathrm{a}(9.29)$ \\
\hline
\end{tabular}

-Means bearing same letter within the same column do not differ significantly at 5\% level following DMRT.

- Figures in parenthesis indicate transformed value.

Table 5: Effect of different plant extracts on yield contributing charactersof purple blotch of onion

\begin{tabular}{|c|c|c|c|}
\hline Treatment & $\begin{array}{c}\text { Umbel } \\
\text { diameter }(\mathrm{mm})\end{array}$ & $\begin{array}{c}\text { Weight of seed } \\
(\mathrm{g}) / \text { umbel }\end{array}$ & $\begin{array}{c}\text { Seed yield }(\mathrm{g}) / \\
\text { plot }\end{array}$ \\
\hline $\mathrm{T}_{1}=$ Dhatura & $51.69 \mathrm{~b}$ & $0.960 \mathrm{a}$ & $92.67 \mathrm{c}$ \\
\hline $\mathrm{T}_{2}=$ Dholkalmi & $48.43 \mathrm{~d}$ & $0.840 \mathrm{ab}$ & $65.00 \mathrm{ef}$ \\
\hline $\mathrm{T}_{3}=$ Garlic & $48.67 \mathrm{~d}$ & $0.723 \mathrm{ab}$ & $66.00 \mathrm{ef}$ \\
\hline $\mathrm{T}_{4}=$ Ginger & $50.55 \mathrm{c}$ & $0.766 \mathrm{ab}$ & $72.00 \mathrm{de}$ \\
\hline $\mathrm{T}_{5}=$ Marigold & $49.67 \mathrm{c}$ & $0.726 \mathrm{ab}$ & $82.67 \mathrm{~cd}$ \\
\hline $\mathrm{T}_{6}=$ Neem & $52.46 \mathrm{~b}$ & $1.067 \mathrm{a}$ & $109.30 \mathrm{~b}$ \\
\hline $\mathrm{T}_{7}=$ Nymbicidine & $53.83 \mathrm{a}$ & $0.853 \mathrm{ab}$ & $135.00 \mathrm{a}$ \\
\hline $\mathrm{T}_{8}=$ Control & $46.23 \mathrm{e}$ & $0.473 \mathrm{~b}$ & $55.00 \mathrm{f}$ \\
\hline
\end{tabular}

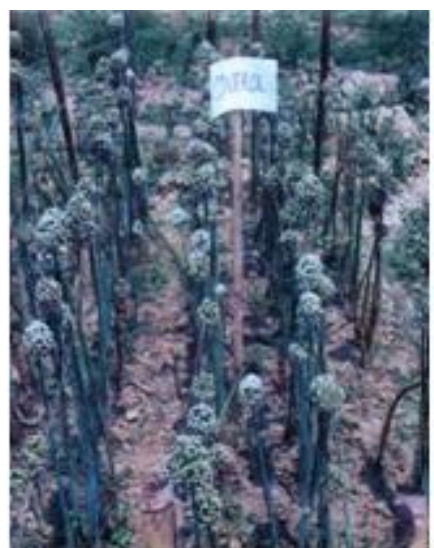

Control

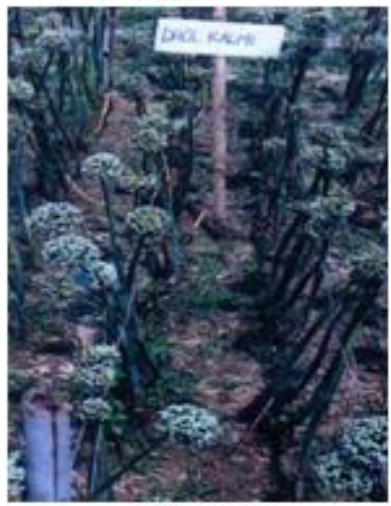

Dholcolmi

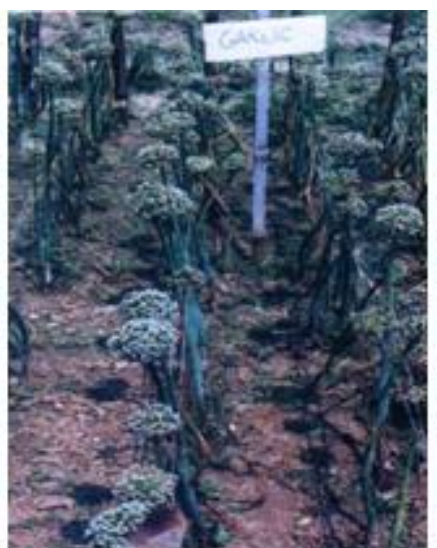

Garlic

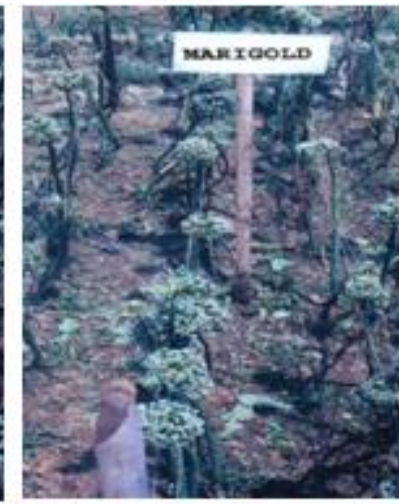

Marigold
-Means bearing same letter within the same column do not differ significantly at 5\% level following DMRT

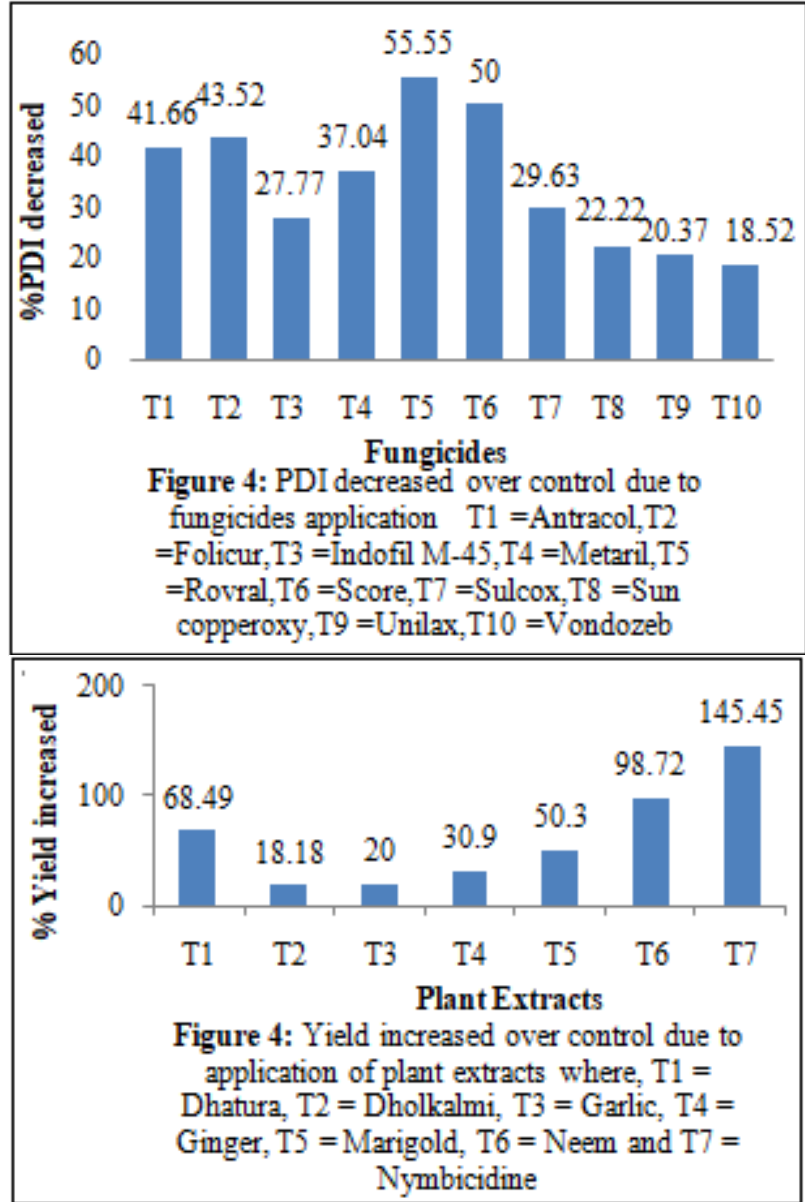

Plate 2: Fungitoxicity of some plant extracts in minimizing purple blotch disease of onion

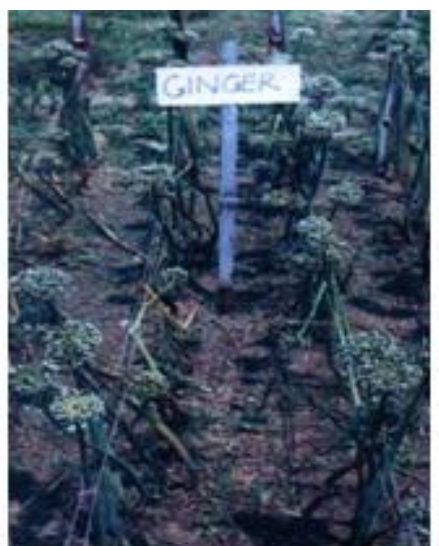

Ginger

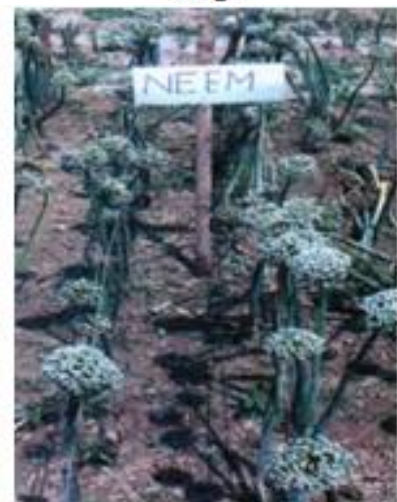

Neem

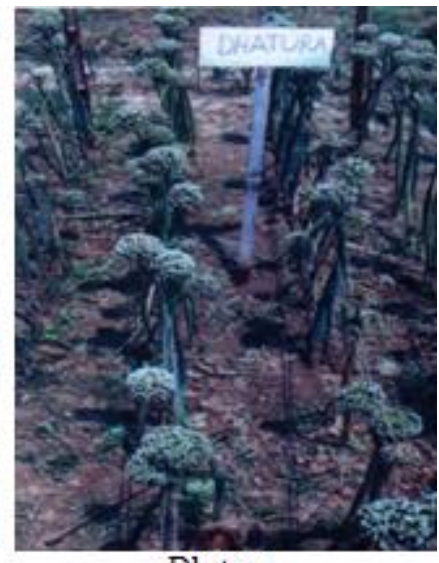

Dhatura

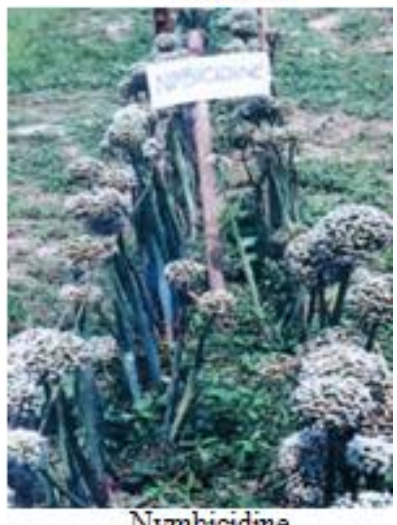

Nymbicidine

\section{Volume 9 Issue 10, October 2020}

\author{
www.ijsr.net
}

Licensed Under Creative Commons Attribution CC BY 


\section{International Journal of Science and Research (IJSR) \\ ISSN: 2319-7064}

ResearchGate Impact Factor (2018): 0.28 | SJIF (2019): 7.583

\section{Discussions}

Under the study 10 fungicides viz. Antracol, Folicur, Indofil M-45, Metaril, Rovral, Score, Sulcox, Sun copperoxy, Unilax and Vondozeb were evaluated both in vitro and in vivo to evaluate their affectivity in controlling purple blotch of onion caused by Alternaria porri and their influence on yield. Results indicate that there was significant variation among the fungicides in their efficacy. All the fungicides were not equally effective. Of the fungicides tested, Rovral scored the best in performance followed by score, Folicur and Antracolin vitro. Metaril was only effective at $2000 \mathrm{ppm}$ to inhibit the growth of $A$. porri. The fungicides performed statistically similarly almost in all parameters. But in in-vitro assay, Antracol and Folicur were found equally significantly effective, irrespective of concentrations. They showed to be statistically similar at only twohigher concentrations (2000 and $1000 \mathrm{ppm}$ ) of Rovral. Score appeared less effective compared to Antracol and Folicur, irrespective of concentrations, in vitro. Metaril was only effective at 2000 ppm to inhibit the growth of $A$. porri. The fungicides Indofil M-45, Sulcox, Sun Copperoxyand Unilax were more or less effective against purple blotch. The present finding on effectiveness of Rovral against Alternaria spp. has been corroborated with by many other researchers [9], [10] and [33]-[44].According to [45] more than 75\% disease reduction was obtained using Rovral. [46]opined that iprodione (Rovral) performed excellent in reducing disease intensity of purple blotch and gave highest yield. The effectiveness of Folicur, Metaril, Antracol against purple blotch have also been suggested by [22], [23], [40], [43] and [47]-[53].Under the study Indofil M-45 (mancozeb) was found not so effective to control $A$. porri incidence compared to Rovral, Score, Folicur and Metaril. On the contrary good control of $A$. porri by Dithane M-45 (Mancozeb) have also been reported by many workers under both in vitro and in vivo[2], [8]-[11], [20], [23], [25], [39], [50] and [54]-[60]. [9], [13], [58] and [61]stated that Dithane M-45 was the best among the fungicides to reduce the purple blotch disease incidence and maximizing bulb yields. [62] reported that mancozeb reduced the purple blotch of onion by $23.6 \%$ and increased the yield by $35.0 \%$. The potentiality of copper fungicides against $A$. porri has been documented by many researchers [10], [22], [23], [43], [50], [59]-[61] and [63]-[65]which differed with the present investigation where coper fungicides like sun Copperoxy and Sulcox appeared to be less effective to A. porri. According to [8], however, copperoxycloride was the best to reduce purple blotch and to maximize the highest bulb yield; which the results of this information fail to support. It may indicate the need to investigate wheatherA. porri has developed resistance against copper based fungicides, in the meantime.

Results on evaluation of fungi toxicity of plant extracts to control purple blotch of onion indicate that all of them have some potentiality against the disease but it varied widely among the extracts of plant origin. Of them Nymbicidine, Neem leaf extracts and Datura performed better compared to rest of the plant extracts. Dholkolmi plant extract shows less effectiveness against purple blotch (A. porri); among the plant extracts. The fungitoxic potential of Neem and Datura have been supported by [26], [27] and [66]-[69]. The extracts of garlic, ginger and onion also showed some degree of potential to restrict the infestation of purple blotch. This was in line with the findings of [24]-[26], [67], [68] and [70]-[72] who tested these extracts against a good number of both seed and soil-borne fungi.

\section{Conclusions}

In a field study fungitoxicity of 10 fungicides were tested to locate effective one(s) to combat purple blotch (A. porri) disease of onion using seedlings of local cultivars, transplanted in unit plot of $2.0 \times 1.2 \mathrm{~m}$. The fungicides employed were: Antracol, Folicur, Indofil M-45, Metaril, Rovral, Score, Sulcox, Sun Copperoxy, Unilax and Vondozeb. All the fungicides were used at the rate of $0.2 \%$. A total of three sprays were executed at 10 days interval. It appeared that there were significant variations in effectiveness among the tested fungicides against $A$. porri. Among them Rovral gave best control of the disease (lesion area and PDI) followed by score, Folicur, Antracol, Metaril,Sulcox, Indofil M-45, Sun Copperoxy, Unilax and Vondozeb. More or less similar trend were shown by fungicides in yield contributing characters.

The effectiveness of the fungicides tested in vivo was also evaluated in vitro to evaluate their performance against $A$. porri using poison food technique. The fungicides were tested at four concentrations viz. 250, 500, 1000 and 2000 ppm. Irrespective of concentrations Rovral and Score appeared the best one in inhibiting the growth of $A$. porri followed by Folicur. Among the fungicides Vondozeb and Unilax were proved ineffective to restrict the growth of $A$. porri.

The antifungal effect of six plant extracts (Datura, Dholkalmi, Garlic, Ginger, Marigold and Neem) and one commercial plant product, namely Nymbicidine (ACI crop care division) was evaluated under field condition. Under the study, bulbs of one of local cultivar was planted in unit plot size of $3.0 \times 1.2 \mathrm{~m}$. Nymbicidene was applied at the rate of $2 \mathrm{ml} /$ litre of water while $15 \mathrm{ml} /$ litre of water each plant extract was applied to best their efficiency. Each treatment was replicated thrice. As the crop was seed crop, plant extracts was applied five times at an interval of 10 days. It was found that all the plant extract had some degree of potentiality in reducing disease contributing characters. Of them Nymbicidine $T_{7}$ performed best in minimizing the purple blotch and it differed significantly from rest of the plant extracts. This was followed by $\mathrm{T}_{1}$ (Datura), $\mathrm{T}_{6}$ (Neem), $\mathrm{T}_{2}$ (Dholkolim), $\mathrm{T}_{4}$ (Ginger), $\mathrm{T}_{3}$ (Garlic) and $\mathrm{T}_{5}$ (marigold). Nymbicidine also gave the highest seed yield.

Based on the findings of the present investigation the following conclusions may be made.

i) Fungicides like Rovral, Score, Folicur, Metaril are highly effective to check purple blotch disease of onion

ii) Nymbicidine, Datura, Neem and Dholkolmi are potential plant extracts against Alternaria porri.

Volume 9 Issue 10, October 2020 


\section{International Journal of Science and Research (IJSR) \\ ISSN: 2319-7064}

ResearchGate Impact Factor (2018): 0.28 | SJIF (2019): 7.583

\section{References}

[1] Bangladesh Bureau of Statistics, Year Book of Agricultural Statistics of Bangladesh, Statistics Division, Ministry of Planning, Dhaka, 2016-17.

[2] Ashrafuzzaman and M.U. Ahmed, "Control of foliage disease of onion by spray fungicides," Bangladesh Hort., 4(2): 25-30, 1976.

[3] D.C.L.Munoz, J.J.P. Martinez and A.P. Perez, “Onion seed production under tropical conditions,"Humbaldt Inst. Fund. Res. Trop. Agric. Acad. Sci., 10(2): 42-45, 1984.

[4] H.U. Ahmed, and M.M. Hossain, "Final report of the project crop disease survey and establishment of a herbarium at BARI," Plant Pathology Divn. BARI, Joydebpur, Gazipur, 170 pp, 1985.

[5] T.K. Bose and G.M. Som,Vegetable crops in India,NayaProkash, Calcutta, India.567-569 pp, 1986.

[6] J.J. Castellanos-Linares, F. Auchet-Jencens and I. Garcia-Correosa,"Effect of Alternaria porri (Ell.)Cif.on onion seed production under experimental conditions in Cuba,'In Rev. Pl. Pathol., 67: 2730, 1988.

[7] S.R. Ahmed and J.P. Goyal, "Control of purple blotch on onion with fungicides," Phytophylactica, 2092): 85186, 1988.

[8] R.P. Gupta, V.K. Srivastava, and U.B. Pandey, "Effect of different fungicides on the control of purple blotch disease of onion bulb crop,'Pl. Path. Lab. Associated Agric. Dev. Foundation East Kailash, New Delhi 110065, India, Pesticides, 21 (5): 33-34, 1987.

[9] M. L. Rahman, H. U. Ahmed and I. H. Mian, "Efficacay of fungicides in controlling purple leaf blotch of onion," Bangladesh J. Plant Path., 4(1\&2): 71-76, 1988

[10] S. Yazawa, "Onion seed production in Srilanka R.P.P.," 72(7): 526, 1993.

[11] S.R. Sharma, "Effect of fungicidal sprays on purple blotch and bulb yield of onion," Indian Phytopath., Indian Inst. Hort. Res. Bengalore 560080, Karnataka, India, 39(1): 78-82,1986.

[12] T.S.Thindand J.S. Jhooty,“Association of thrips with purple blotch infection on onion plants caused by Alternaria porri," Indian Phytopathol, 35: 696-698, 1982.

[13] K.S. Sandhu, S.S. Gill and H. Singh,"Effect of cultural practices on purple blotch disease in onion seed crop," Hort. Abs., 53: 1654, 1983.

[14] S.N.Vishwakarma, "Economics of chemical control of purple blotch Alternaria porri of onion seed crop," Pestology, Bombay, 10(6): 18-21, 1986.

[15] R.B.L. Guptaand V.N. Pathak,"Effect of age of host inoculum density and duration of high relative humidity on development of purple blotch of onion,'Phytophylactica 18(3): 151-152, 1986.

[16] D. Mishra, I.C. Mahanta, P.K., Chhotaray,"Chemical control of purple blotch of onion in Orissa," Orissa J. of Agric. Res., (1): 25-28, 1989.

[17] S.K. Sugha, P.D. Tyagi and R.K. Develash,"Effect of heat treatment of bulb and spray of fungicides in management of purple blotch (Alternaria porri) of onion (Allium cepa)," Indian J. Agril. Sci., 63(5): 303-305, 1993.
[18] P.K. Srivastava, R.C. Sharma and R.P. Gupta,"Effect of different fungicides on the control of purple blotch and Stemphylium blight diseases in onion seed crop,"Newsl. Natl. Hort. Res. Dev. Found., 15(3): 6-9, 1995.

[19] N. Ahmed and K. Sultana,"Fungitoxic effect of garlic on treatment of jute seed," Bangladesh J. Bot., 13: 130-136,1984.

[20] U.P. Singh, R.P. Srivastava, K.P. Singh and G.D. Mishra,"Control of powdery mildew of pea by ginger extract," Indian Phytopath, 44(1): 55-59, 1991.

[21] B.N.Bhowmickand V. Vardhan, "Antifungal activity of some leaf extract of medicinal plants on Curvulariatunata," Indian Phytopath, 34: 386, 1991.

[22] H.S.Sarvamangala and R.K. Datta,"Evaluation of plant extracts for the control of fungal diseases of mulberry," Indian Phytopath. 46(4): 398-401, 1993.

[23] B.E. Wheeler, An introduction to plant diseases, John Willey and Sons, Ltd., U. K, pp. 301, 1969.

[24] M.R. Islam, N. Akhter,S.M. Chowdhury,M. Ali, and K.U. Ahmed, "Evaluation of Fungicides against Alternaria porri Causing Purple Blotch of Onion," Journal of Agricultural Science and Technology, 2, 27 30, 2003.

[25] M.B. Ellis, DematiaceousHyphomycetes. Commonwealth Mycol. Institute, Kew, Surrey, England, 608 p, 1971.

[26] M.J.Tuite, Plant Pathological Method: Fungi and Bacteria, Purdue University, Lapyette, Indiana, U.S.A., 239p, 1969.

[27] K.A. Gomez and A.A.Gomez, Statistical Procedure for Agricultural Res. ( $2^{\text {nd }}$ Ed.)John Wiley and Son.Singapore, pp. 188-192, 1984.

[28] B. Jouan, J. M. Lemaire and Y. Herve,"Studies on diseases of cauliflower. I. Pathogens of seed plant of cauliflower,"Annales-de-Phytopathologiae 4(2):133$135,1972$.

[29] R. B.Maude, "Alternaria. Routine sprays to check seed crop disease now under test," Grower 88(7): 288-291, 1977.

[30] L. Miura, "Control of fungi on onion seeds," Pesquisaem.Andamento EMPASC, Florianopolis, Brazil, No. 45, 2pp, 1985.

[31] M.G.Anderson, Cabbage storage decay control, Ann. Rep. Sta. Kentville. Nova.Scotia.Canada, pp. 115, 1986.

[32] G. Bedlan, "Control of leaf spot in chinese cabbage," Rev. Plant Path., 67:4169, 1987.

[33] D. Esiyok, N. Cetindaya, E. Onogur and B. Eser,"Preliminary results on the relations between cultivation methods, fungicide application and disease incidence in the seed production of early cauliflower variety (cv. Brio),'CruciferaeNewslettes 13:130-131, 1988.

[34] P.P.Sinhaand R. K. Prasad,"Chemical management of Alternariablight of cauliflower seed crop," Indian J. Mycol. and Plant Pathol., 19(2):204-205, 1989.

[35] E. Barnoczki-Stoilova, A. Barnoczki, F. Szalay, J. Hirka and S. Varga, "The effect of plant protective sprays applied during flowering on onion Yields and seed quality"Zoldseg-termesztesiKutatoIntezet, Bulletinje,Kecskemet, Hungary, 22, 115-121, 1989.

[36] Perez-Moreno, Luis, Chavez-Hernadez, LuisFelipe,"Genotype and fungicide evaluation for control 


\section{International Journal of Science and Research (IJSR) \\ ISSN: 2319-7064}

ResearchGate Impact Factor (2018): 0.28 | SJIF (2019): 7.583

of purple spot (Alternaria porri) and downy mildew peronospora destructor (Berk) caps] of onion (Allium cepa L.) in Irapuato," GTO. Universidad de Guanjuato, (Mexico), Esculea de Agronomia Y Zootecnia, Apdo. Postal 311, Irapauato, Gto. 36500. Ravista-Mexicanade-Fitopatologia (Mexico), V. 10(1). p. 29-34, 1992.

[37] M. Babadoost, “Control of Alternaria diseases of brassica seed crops caused by Alternaria brassicae and A. brassicicola with ground and aerial fungicide applications," Seed Sci. and Technology, 21(1):1-7, 1993.

[38] S.K.Sugha, "Management of purple blotch (Alternaria porri) of garlic with fungicides," Indian J. Agril. Sci. 65(6):455-458, 1995.

[39] A. Ayub, T. K. Dey, M. Jahan, H. U. Ahmed and K. B. Alam, "Foliar spray of fungicides to control Alternaria blight of mustard," Annals of Bangladesh Agriculture, 6(1):47-50, 1996.

[40] N. Filajdic and T. B. Sutton, "Chemical control of Alternaria blotch of apples caused by Alternaria mali," Plant Disease, 76(2):126-130, 1992.

[41] N.I. Georgy, I.A. Radwan, H.A. Mohammed and A.E.Shahabi, "Chemical Control of downy mildew and purple leaf blotch of onion in Egypt," Agricultural Research Review, P1. Path Res. Inst. Agric. Res. Cent. Minist. Agric. Egypt, 61(2): 25-41, 1983, Publ. 1986.

[42] E.W. Ryan, W. P. Staunton and J. C. Cassidy,"Diseases of vegetables," Rev. Plant Path., 63:5178, 1984.

[43] R.S. Ramos, E. Issa, C. Sinigaglia and S. Chiba,"Chemical control of downy mildew (Peronospora destructor (Berk.)Casp.)and purple spot (Alternaria porri (Ell.) Cif.)of onion (Allium cepaL.)," Hort. Abs., 55: 7618, 1985.

[44] M. Tahir, M. Shah, M. Khan, A. Samad and S.F.A. Shah, "Chemical control of purple disease of onion,"Sarhad J. of Agriculture, 7(3): 373-376, 1991.

[45] T.A.S. Aveling, H.G. Snyman and S.P. Haude,"Evaluation of seed treatments for reducing Alternaria-pori and Stemphyliumvesicariumon onion seed," Plant disease, 77(10): 1000-1011, 1993.

[46] J.F.G.Rochecouste, "Chemical control of garlic rust," Australian Pl. Path., 13(3):47-48, 1984.

[47] A.I. El-Shehaby, I.A. Radwan, F.N. Husien, S. Korayem, M.F.I Tadrous and M.W. Azab, "Evaluation of fungicides for controlling downy mildew and purple blotch diseases of onion," Egyptian J. Agril. Res., 73(4): 913-924, 1995.

[48] P.S.Bediand Y.S. Gill,"Purple blotch of onion and its control in the Punjab" Indian J. Mycol. and Plant Pathol., 8(1):40, 1978.

[49] Y.L. Nene and P.N. Thapliyal, "Fungicides in plant disease control" Oxford and IBH Pub.Co., New Delhi, Bombay and Calcutta, India, 379p, 1979.

[50] S.M.H. Quadri, K.J. Srivastava, S.R. Bhonde, U.B. Pandey and P.M. Bhagchaudani, "Fungicidal bioassay against some important pathogens of onion," Pesticides 16: 11-16, 1982.

[51] A.K. Sharma, "Field evaluation of some common fungicides for control of purple blotch of onion," Pesticides, 21(9): 39-42, 1987.

[52] R.P. Gupta, P.K. Srivastava, K.J. Srivastava and B.S. Bhardway, "Prevalance of onion disease and insect pests in India and strategy for effective pest management,"Newsletter Associated Agricultural Development Foundation, Nasik, 422001, India, 11(3): 7-11, 1992.

[53] V.V. Datar, "Chemical management of purple blotch of onion in India," TVIS Newsletter. 1(2): 23-24, 1996.

[54] K.J. Srivastava, S.M.H. Qadri, B.K. Tiwari and S.R. Bhonde, "Chemical control of purple blotch of onion bulb in kharif season," Indian Phytopathology, 44(2): 251-253, 1991.

[55] D.N.Padule and P.G. Utikar."Evaluation of fungicides for the control of Alternaria blight on onion," Madras Agril. J., 64(10): 693-694, 1977.

[56] M.B.Joiand H.N. Sonone, "Evaluation of nine fungicides for the control of leaf blight (Alternaria cepulicolaRac) or onion in Maharashtra," J. Maharashtra Agril. Univ., 3(3): 211-213, 1978.

[57] Kolte-SO, Dhawale-HR and Thakre-KG,"Fungicidal control of Alternaria porri (Ellis) leaf blotch onion under field conditions," PKV-Research Journal,17:2. 176-179,1993.

[58] K.J.Srivastava and R.P. Gupta, "Efficacy of pesticide combinations on the control of disease blotch disease and thrips in onion seed crop," Newsletter-Associated Agricultural Development Foundation, Nashik 422001, India, Horticultural Abstracts, V. 65 (5). p. 500, 1993.

[59] Upadhyay-J and Tripathi-KC, "Field evaluation of fungicides against purple blotch of onion Seed Crop," Recent Horticulture, 2:2, 153-155, 1995.

[60] P. Lakshmanan, S. Mohan and R. J. Eyarajan,"Antifungal properties of some plant extracts against Thanatephoruscucumeris, the causal agent of coller rot disease of Phaeolusaureun," Madras Agric. J., 77(1): 1-4, 1990.

[61] M.A.T. Mia, H.U. Ahmed, N.R. Sharma, A. Ali and S.A. Miah, "Antifungal activity of some plant extracts,” Bangladesh J. Botany, 19(1): 5-10, 1990.

[62] M.A. Basharand B. Rai,“Antifungal activity of extracts of some plant parts against Fusariumoxysporumf. sp Cicero,” Bangladesh J. Botany, 20(2): 219-222, 1991.

[63] I.Hossainand E. Schlosser, "Control of Bipolarissorokiniana in wheat with neem extracts," Bangladesh J. Microbiol., 10(1): 39-42, 1993.

[64] N.S.Murtyand K. Nagarajan,"Role of plant extracts in the control of TMV infection in nursery and field grown tobacco," Indian Phytopath, 39: 98-99, 1986.

[65] R.G.Dubeyand R.S. Dwivedi, "Fungitoxic properties of some plant extracts against vegetative growth and sclorotial viability of Macrophominaphasoolina," Indian Phytopath, 44: 411-423, 1991.

\section{Author Profile}

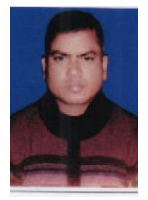

Md. Mozidul Islam received the B.S. in Agriculture from Sher-e- Bangla Agricultural University, Sher-eBangla Nagar, Dhaka, Bangladesh in 2000 and M.S. in Plant pathology from Bangladesh Agricultural University, Mymensingh, Bangladesh in 2003, respectively. $\mathrm{He}$ is now working as Assisstant Horticulture Development Officer, Department of Agricultural Extension, Dhaka, Bangladesh. 